PRZEGLĄD NAUK HISTORYCZNYCH 2020, R. XIX, NR 1

http://dx.doi.org/10.18778/1644-857X.19.01.09

\title{
Krótkie życie i niespodziewana śmierć młodego magnata. Janusz Pawel ks. Ostrogski i jego testament z 6 sierpnia 1619 roku
}

Streszczenie. Artykuł poświęcony jest postaci księcia Janusza Pawła Ostrogskiego (1597-1619). Był on potomkiem jednej z najpotężniejszych rodzin magnackich w Rzeczypospolitej. Po wczesnej śmierci ojca, wojewody wołyńskiego Aleksandra, wychowywany był wraz ze starszym bratem przez matkę. Doprowadziła ona do konwersji synów z prawosławia na katolicyzm. W latach 1611-1615 młodzi Ostrogscy odbyli podróż edukacyjna po Europie. Po powrocie do kraju przejęli $z$ rak matki ogromne latyfundium. Obaj bracia znani byli $z$ hulaszczego trybu życia i rozwiązłości. Zarazili się kiłą, co było przyczyną ich przedwczesnej śmierci. Po zgonie starszego brata Janusz Paweł stał się jednym $z$ największych właścicieli ziemskich w Rzeczypospolitej. Zamierzał się ożenić. Śmierć zaskoczyła go jednak w drodze do domu przyszłego teścia. Książe sporząził przed śmiercią ciekawy testament, którego krytyczna edycja została zamieszczona jako aneks do tego opracowania.

Słowa kluczowe: Książę Janusz Paweł Ostrogski, magnateria polska, dzieje Rzeczypospolitej w XVII wieku, testamenty staropolskie, edycja źródłowa.

J

anusz Paweł ks. Ostrogski był potomkiem jednej z najpotężniejszych rodzin magnackich w Rzeczypospolitej przełomu XVI i XVII w. Urodził się jako jedno z ośmiorga dzieci wojewody wołyńskiego Aleksandra i Anny z Kostków, wojewodzianki sandomierskiej. Zanim przejdziemy do omówienia losów kniazia Janusza Pawła, wypada poświęcić kilka słów jego rodzicom. Ojciec, urodzony w 1570 r., był najmłodszym synem najbogatszego magnata

* Wydział Filozoficzno-Historyczny, Instytut Historii, Katedra Historii Nowożytnej, e-mail: zbigniew.anusik@uni.lodz.pl 
w Koronie, wojewody kijowskiego Konstantego Wasyla ks. Ostrogskiego (zm. 1608), wielkiego protektora prawosławia i przeciwnika unii brzeskiej. Matka Aleksandra, Zofia Tarnowska, która zmarła w połogu po jego urodzeniu, była $z$ kolei córka kasztelana krakowskiego i hetmana wielkiego koronnego Jana Amora Tarnowskiego (zm. 1561). Wychowywany przez owdowiałego ojca, który nie ożenił się po raz drugi, Aleksander ks. Ostrogski do końca życia pozostał gorliwym wyznawca prawosławia. W 1593 r. poślubił Annę Kostczankę (1575-1635), córkę wojewody sandomierskiego Jana ze Sztemberku Kostki (zm. 1581) i Zofii Odrowążówny, wojewodzianki ruskiej. Matka księcia Janusza Pawła pochodziła $z$ rodziny znanej $z$ przywiązania do rzymskiego katolicyzmu i sama również była gorliwa katoliczką. Zgodnie ze zwyczajem epoki synowie tej pary mieli pozostać przy prawosławiu, czyli wyznaniu ojca, podczas gdy córki od dzieciństwa były wychowywane przez matkę w duchu katolickim ${ }^{1}$. Jak wspomniano, w ciagu 10 lat małżeństwa Anna z Kostków ks. Ostrogska urodziła ośmioro dzieci. Najstarsza $z$ rodzeństwa była niewatpliwie Zofia. Jako drugi, najpewniej w roku 1596, urodził się Adam Konstanty (w źródłach nazywany najczęściej Konstantym). Potem kolejno pojawiali się na świecie: Janusz Paweł, Aleksander, Katarzyna, Anna Alojza, Krzysztof i Wasyl. Możemy zatem $z$ dużą doza prawdopodobieństwa założyć, że nasz bohater urodził się w 1597 r. $^{2}$ Bardzo wcześnie kniaź Janusz stracił ojca.

${ }^{1}$ Por. H. Kowalska, Ostrogski Aleksander, [w:] Polski słownik biograficzny [dalej: PSB], t. XXIV, Wrocław 1979, s. 480; e a d e m, Ostrogska Anna z Kostków, [w:] ibidem, s. 478-479; S. Kardaszewicz, Dzieje dawniejsze miasta Ostroga. Materyały do historyi Wołynia, Warszawa-Kraków 1913, s. 44; T. Ke m pa, Dzieje rodu Ostrogskich, Toruń 2003, s. 127-128; N. J a kow e n ko, Ukraijnska szljachta $z$ kinca XIV - do seredyny XVII stolittja. Wołyn' i Centralna Ukraijna, Kyijw 2008, s. 308. We wszystkich tych opracowaniach podano jednak błędnie, że Aleksander ks. Ostrogski poślubił Annę z Kostków w 1592 r. Tymczasem wiadomo, że stryj i opiekun Anny, wojewoda pomorski Krzysztof Kostka obiecał jej rękę kasztelanowi wojnickiemu Janowi Tęczyńskiemu. Do ślubu jednak nie doszło z powodu niespodziewanej śmierci Tęczyńskiego, który zmarł 1 I 1593 r. Jest więc sprawą oczywistą, że małżeństwo wojewodzianki sandomierskiej z księciem Ostrogskim zostało zawarte przynajmniej kilka miesięcy po tej dacie. Por. Z. Os solińs ki, Pamiętnik, oprac. J. Długosz, Warszawa 1983, s. 35. Por. też A. To m czak, Kostka Krzysztof, [w:] PSB, t. XIV, Wrocław-Warszawa-Kraków 1968-1969, s. 351 (tu informacja, że ślub Aleksandra ks. Ostrogskiego z Anną Kostczanką miał miejsce w 1593 r., a szumne wesele tej pary odbyło się na zamku w Golubiu).

${ }^{2} \mathrm{~W}$ dotychczasowej literaturze przedmiotu brakuje informacji o datach narodzin większości dzieci Aleksandra i Anny ks. Ostrogskich. Panuje jednak konsensus co do tego, że Adam Konstanty przyszedł na świat w 1596, a Anna Alojza 
Wojewoda wołyński Aleksander ks. Ostrogski zmarł bowiem nagle, w wieku zaledwie 33 lat, 12 grudnia 1603 r. w Krasnem, w województwie bracławskim ${ }^{3}$.

Ojciec księcia Janusza Pawła był człowiekiem dumnym i gwałtownym. Trudny charakter księcia Aleksandra leżał u podstaw konfliktów, głównie natury majątkowej, z jego najstarszym bratem, kasztelanem krakowskim Januszem. Uniemożliwiał też przez wiele lat wypracowanie jakiegoś kompromisu w sprawie podziału ogromnego majątku wojewody kijowskiego Konstantego Wasyla. Ten ostatni, widząc narastająca wrogość między swoimi synami (obaj gotowi byli użyć siły zbrojnej w walce o przejęcie jak naj-

w 1600 r. Skoro tak, to Zofia, która już 10 XI 1613 r. poślubiła Stanisława Lubomirskiego (późniejszego wojewodę krakowskiego), musiała urodzić się w 1594 lub też, co wydaje się bardziej prawdopodobne, w $1595 \mathrm{r}$. Na podstawie akt Trybunału Koronnego możemy zaś stwierdzić, że synowie wojewody wołyńskiego rodzili się w następującej kolejności: Adam Konstanty, Janusz Paweł, Aleksander, Krzysztof i Wasyl. Wiemy też na pewno (rozstrzyga o tym kolejność zawartych małżeństw), że Katarzyna była starsza od Anny Alojzy. Trzeba więc przyjąć, że skoro Adam Konstanty urodził się w 1596 r., to Janusz Paweł przyszedł na świat w roku 1597, Aleksander w 1598, Katarzyna w 1599 (jest również możliwe, że była ona starsza od Aleksandra), a Anna Alojza w 1600 r. Najmłodsi z rodzeństwa - Krzysztof i Wasyl urodzili się już w XVII stuleciu. Por. A. Boniecki, Poczet rodów w Wielkiem Księstwie Litewskiem w XV i XVI wieku, Warszawa 1887, s. 236-237 (tu błędne stwierdzenie, że najstarszym $z$ wojewodziców wołyńskich był Aleksander); J. Wolff, Kniaziowie litewsko-ruscy od końca XIV wieku, Warszawa 1895, s. 358-359; S. Kardaszewicz, op. cit., s. 44, 47 (tu stwierdzenie, że Aleksander ks. Ostrogski miał tylko dwóch synów, a starszy z nich - Konstanty urodził się 25 III 1597 r.); H. Kowalska, Ostrogski..., s. 480; N. J akowenko, op. cit., s. 308 (z błędami); Por. też Wyciagi z summaryusza Aktów Trybunału Lubelskiego, [w:] Źródła dziejowe, t. XXI (Polska XVI wieku pod względem geograficzno-statystycznym, t. X, Ziemie ruskie, Ukraina [Kijów-Brackaw], dział II-gi), wyd. A. Jabłonowski, Warszawa 1894, s. 106, 160, 519, 534, 540, 544 (tu regestry spraw z lat 1606, 1607 i 1609, w których jako strony występuja wojewodzice wołyńscy Konstanty i Janusz ks. Ostrogscy).

${ }^{3}$ Por. S. Kardaszewicz, op. cit., s. 44 (tu informacja, że Aleksander ks. Ostrogski zmarł 2 XII 1603 r.); J. Wolff, op. cit., s. 358 (tu 13 XII 1603 r. jako data śmierci wojewody wołyńskiego). Warto zwrócić uwage na to, że cytowany tu autor dokonał złego przeliczenia datacji z kalendarza juliańskiego na kalendarz gregoriański. Według starego stylu 2 XII 1603 r. to nie 13, a 12 XII 1603 r. według stylu nowego. Nagła śmierć Aleksandra ks. Ostrogskiego zrodziła podejrzenia o to, że został on otruty. Piszą o tym: J. J e rlicz, Latopisiec albo kroniczka, wyd. K.W. Wójcicki, Warszawa 1853, s. 33; oraz S. Kardaszewicz, op. cit., s. 44. W uzupełnieniu dodajmy, że Aleksander ks. Ostrogski, który od czasu ślubu z Anna Kostczanką rezydował najczęściej w Jarosławiu, zmarł w czasie objazdu swoich ukrainnych posiadłości. Por. T. Kempa, op. cit., s. 61 (tu miejsce i prawidłowa data zgonu wojewody wołyńskiego). 
większej części majątku ojca), postanowił jeszcze za swego życia wydzielić im należne schedy. Poproszony o mediację, dawny klient Ostrogskich, ówczesny wojewoda podolski Aleksander Koniecpolski pomyślnie wywiązał się ze swojej roli i w marcu 1603 r. zapośredniczył ugodę między książętami Januszem a Aleksandrem. W maju tego roku akt podziału majątku wojewody kijowskiego między jego synów został wniesiony do grodu w Nowym Mieście Korczynie oraz do ksiag Trybunału Koronnego w Lublinie. Ogromne latyfundium Konstantego Wasyla ks. Ostrogskiego obejmowało wówczas 50 miast, 937 wsi i 106 folwarków, a jego posiadłości w trzech województwach kresowych (wołyńskim, kijowskim i bracławskim) zajmowały powierzchnię około $19100 \mathrm{~km}^{2}$. Na mocy ugody podziałowej kasztelan krakowski Janusz ks. Ostrogski otrzymał 19 miast, 453 wsie i 48 folwarków, a wojewoda wołyński Aleksander 31 miast, 484 wsie i 58 folwarków. Należy jednak zaznaczyć, że na części przyznanych synom majątków wojewoda kijowski zastrzegł sobie dożywocie. Niespodziewana śmierć księcia Aleksandra spowodowała zaostrzenie stosunków między wdową po nim a jej teściem i szwagrem. Ostrogscy zgłosili bowiem pretensje do sprawowania opieki nad dziećmi i majatkiem wojewody wołyńskiego. Ostatecznie jednak w wyniku ugody zawartej w Lublinie 13 lipca 1604 r. Anna z Kostków ks. Ostrogska otrzymała pełne prawo do dysponowania majątkiem po mężu oraz do sprawowania opieki nad dziećmi. Jedynie w sprawie wydania córek za mąż miała zasięgać rady książąt Konstantego Wasyla i Janusza. W maju 1608 r., niedługo po śmierci wojewody kijowskiego, który zmarł 23 lutego tego roku, dokonano podziału pozostałych po nim ruchomości, a księżna Anna zeznała wówczas, że nie ma żadnych pretensji do kasztelana krakowskiego. W rzeczywistości jednak stosunki między panią na Jarosławiu a księciem Januszem nigdy znacznie się nie poprawiły, gdyż ten ostatni do końca swego życia prowadził liczne spory $z$ bratową i jej synami ${ }^{4}$.

${ }^{4}$ Por. S. Kardaszewicz, op. cit., s. 43-44; T. Kempa, Konstanty Wasyl Ostrogski (ok. 1524/ 1525-1608), wojewoda kijowski i marszałek ziemi wołyńskiej, Toruń 1997, s. 239-242; idem, Dzieje rodu..., s. 130-132; Z. Anusik, Glosa do dziejów rodu ksiażąt Ostrogskich, „Przegląd Nauk Historycznych” 2008, R. VII, nr 1, s. 171-175; ide m, $Z$ dziejów rodu ksiażąt Ostrogskich, [w:] ide m, Studia i szkice staropolskie, Łódź 2011, s. 454-457. 
W latach 1605-1607 zmarli kolejno młodsi bracia Janusza Pawła - Wasyl, Krzysztof i Aleksander ${ }^{5}$. Troskliwa matka $z$ tym większym oddaniem zajęła się wychowaniem i wykształceniem dwóch najstarszych synów, $z$ otoczenia których po śmierci teścia usunęła prawosławnych nauczycieli. Pod jej wpływem, na przełomie 1608 i 1609 r. młodzi książęta przeszli na katolicyzm. Obaj też jeszcze w 1609 r. zostali uczniami kolegium jezuickiego w Jarosławiu, gdzie uczyli się do $1611 \mathrm{r}$. W tym bowiem roku w jarosławskim kolegium wystawiono tragikomedię $z$ okazji ukończenia szkoły przez Adama Konstantego i Janusza Pawła ks. Ostrogskich ${ }^{6}$. Wkrótce po zakończeniu nauki w Jarosławiu, zapewne jeszcze w 1611 r. młodzi Ostrogscy udali się w podróż zagraniczną. W czasie jej trwania studiowali przez czas jakiś na uniwersytecie w Lowanium, w Ratyzbonie zostali przyjęci na audiencji przez cesarza Macieja, a w Rzymie przez papieża Pawła V. Zwiedzili zatem Południowe Niderlandy, Niemcy i Włochy, a być może również Francję i Hiszpanię ${ }^{7}$.

${ }^{5}$ Por. A. Boniecki, op. cit., s. 237 (tu Wasyl zm. 1605, Krzysztof zm. przed 1607, a Aleksander zm. przed 1608); J. Wolff, op. cit., s. 358 (tu Wasyl zm. 1605, Krzysztof zm. 1606, Aleksander zm. 1607); N. Jakowenko, op. cit., s. 308 (tu Aleksander zm. 1597, Krzysztof zm. 1604, a Wasyl zm. 1605); H. Kowalska, Ostrogski..., s. 480 (tu Aleksander zm. ok. 1607, Krzysztof zm. 1607, a Wasyl zm. 1605).

${ }^{6}$ Por. W. Czapliński, J. Długosz, Życie codzienne magnaterii polskiej $w$ XVII wieku, Warszawa 1976, s. 148.

7 W starszej literaturze przedmiotu, wychodzacc z błędnego założenia, że sławny później Szymon Starowolski był ochmistrzem młodych książąt, próbowano dostosować daty podróży edukacyjnej Ostrogskich do faktów znanych z życiorysu ich „opiekuna”. Ponieważ zaś wiadomo, że 10 XII 1612 r. Starowolski rozpoczał studia w Akademii Krakowskiej, podróż zagraniczna książąt Ostrogskich datowano zwykle na lata 1608-1611 lub też 1609-1612. Wielki polihistor pisał później o swoim pobycie w Lowanium, gdzie musiał być razem z Ostrogskimi. W ich orszaku nie pełnił jednak funkcji ochmistrza, a „chłopca do różnych posług”. Po zakończeniu pobytu książąt w Południowych Niderlandach został też prawdopodobnie odesłany wraz z częścią zbędnej już czeladzi do domu. Adam Konstanty i Janusz Ostrogscy udali się zaś do Niemiec, gdzie doszło do ich spotkania z cesarzem Maciejem. Stało się to niewatpliwie w czasie obrad Sejmu Rzeszy w Ratyzbonie (tylko wtedy przebywał bowiem w tym mieście cesarz), który obradował od 24 IV do 13 VIII 1613 r. $Z$ cała pewnością Ostrogscy na dłuższy czas zatrzymali się też we Włoszech. Nie jest natomiast pewne, czy po zwiedzeniu Italii udali się jeszcze do Francji i Hiszpanii. Swoją podróż edukacyjną zakończyli zapewne w pierwszej połowie $1615 \mathrm{r}$. Por. A. Piskadło, Wstęp, [w:] S. Starowolski, Polska albo opisanie położenia Królestwa Polskiego, oprac. A. Piskadło, Kraków 1976, s. 9-10; A. Biedrzycka, J. Tazbir, Starowolski (Starovolscius) Szymon, [w:] PSB, t. XLII, Warszawa- 
Do rodzinnego Jarosławia powrócili w połowie $1615 \mathrm{r}^{8}{ }^{8}$ Trudno powiedzieć, jak wielkie korzyści odnieśli młodzi książęta ze swojej podróży edukacyjnej. Wiemy natomiast, że w czasie swojego pobytu w Europie Zachodniej, szczególnie we Włoszech, bracia Ostrogscy oddawali się różnego rodzaju uciechom, nie stroniąc od licznych miłostek. Prawdopodobnie właśnie wówczas obaj zarazili się kiłą, która stała się w nieodległej przyszłości przyczyną ich przedwczesnych zgonów ${ }^{9}$.

W 1616 r. Anna z Kostków ks. Ostrogska przekazała dorosłym już synom większość dóbr po ich ojcu, zatrzymując jednak w swoim ręku te majętności, na których miała zapis dożywocia. Adam Konstanty i Janusz Paweł, którzy nigdy nie dokonali podziału odziedziczonego po ojcu latyfundium, stali się wówczas pełnoprawnymi właścicielami ogromnych włości położonych w województwach: krakowskim (Rożnów), sandomierskim (Tarnów - połowa miasta

Kraków 2003-2004, s. 356; S. Kardas zewicz, op. cit., s. 47; J. Wolff, op. cit., s. 358 (tu podróż edukacyjna Ostrogskich datowana jest na lata 1612-1614). Osobno wspomnieć trzeba o artykule, którego autor twierdzi, że Ostrogscy wrócili do kraju na wesele swojej siostry Zofii (10 II 1613 r. poślubiła ona Stanisława Lubomirskiego), a w kolejna podróż edukacyjną, w towarzystwie Piotra Kochanowskiego, udał się już tylko Adam Konstanty, którego nazwisko 16 X 1613 r. zostało odnotowane w albumie nacji polskiej uniwersytetu padewskiego. Por. J. Kus, „Wielkie, ale krótko trwałe oyczyzny nadzieje...”. Adam Konstanty $i$ Janusz Paweł ksią̇ęta Ostrogscy, wojewodzice wołyńscy, „Zeszyty Muzealne. Muzeum w Jarosławiu" 1997/1998, R. II, z. 2, s. 9-10. Twierdzenie to zostało jednak oparte na błędnych przesłankach. Ostrogscy wcale nie przerwali bowiem swojej podróży zagranicznej w początkach 1613 r. Kilka miesięcy później obaj uczestniczyli bowiem w spotkaniu z cesarzem Maciejem w Ratyzbonie. Brak wpisu nazwiska Janusza Pawła ks. Ostrogskiego do albumu nacji polskiej uniwersytetu padewskiego świadczy zaś tylko o tym, że nie podjął on studiów na tej uczelni. Nie przesądza natomiast o jego nieobecności we Włoszech w tym czasie.

${ }^{8}$ Por. [K. Wolbromczyk], Charisterion ob felicem ecoptatum illustrissimi Principis Constantini Ostrogii Ducis ab exteris nationibus favente, coleo in patriam reditum. A nobili studiosaque iuventute Collegii Jarroslaviensis SJ... datum anno Christi 1615, Leopoli [1615]; A. Komorowic, Panegyricus... Constantino Duci Ostrogiae... dum salvus et incolumis in Regnum Poloniae redirect... dedicatus et oblatus, Cracoviae 1615. Sądząc na podstawie tego, że panegirykami uczczono jedynie powrót do kraju Adama Konstantego, można przypuszczać, że bracia Ostrogscy rozdzielili się w pewnym momencie swojej podróży i Janusz Paweł wrócił do Jarosławia w innym terminie. Równie dobrze mógł on jednak przez cały czas towarzyszyć starszemu bratu.

9 Por. J. Pietrzak, Akademickie niestatki, czyli o niechlubnym żywocie polskich studentów $w$ podróżach edukacyjnych po Europie Zachodniej od XVI do XVIII wieku, „Biuletyn Historii Wychowania” 2014, nr 32, s. 24 (tu jednak stwierdzenie, że w latach 1613-1615 Ostrogscy podróżowali tylko po Italii). 
i klucza), ruskim (Krakowiec, Przeworsk, Tarnopol), wołyńskim (Berezdów, Dorohobuż, Kniehynin, Krupa, Lubar, Łabuń, Ostropol, Ostróg - połowa miasta i klucza, Połonne, Równe, Satyjów, Smołderów, Suraż, Zwiahel), kijowskim (Barasze, Białogródka, Dymir, Noryńsk), bracławskim (Kobyle, Krasne, Marianów, Raszków, Sutyska, Szpików, Woroszyłówka) oraz w Wielkim Księstwie Litewskim (Słoweńsk, Tarasów, Turów, Zdzięcioł). W sumie dobra te obejmowały 16 zamków, 38 miast, 494 wsie, 213 folwarków oraz 8 wójtostw. Roczny dochód $z$ tych majątków wyliczono zaś w $1621 \mathrm{r}$. (więc już po śmierci obu wojewodziców wołyńskich) na olbrzymia kwotę 203511 florenów $^{10}$. Po przejęciu $z$ rąk matki zarządu wielkiego latyfundium obaj książęta, teraz już na własny rachunek, toczyli w Trybunale Koronnym procesy $z$ sassiadami swoich kresowych majątków ${ }^{11}$. Zarówno Adam Konstanty, jak i Janusz Paweł otoczyli się też liczna grupa dworzan, wśród których nie brakowało ludzi pochodzenia plebejskiego ${ }^{12}$.

Objęcie zarządu dóbr przez braci Ostrogskich stanowiło nadzieję dla mieszkańców kresów, że zapewnia im oni lepsza niż do tej pory obronę przed Tatarami. Pierwsze doświadczenia księcia Janusza Pawła w tym zakresie nie napawały jednak optymizmem. Gdy 1 lutego 1617 r. Tatarzy niespodziewanie pojawili się pod Ostrogiem, młodszy $z$ wojewodziców wołyńskich przebywał w Surażu. Na wieść o najeździe tatarskim, natychmiast ruszył na pomoc i wieczorem stanał w ostrogskim zamku. Kiedy jednak następnego dnia próbował wyprowadzić swoich żołnierzy poza mury miasta, okazało się, że nie zamierzają oni podjąć walki z przeważającym liczebnie wrogiem. Książę Janusz Ostrogski i jego ludzie obserwowali tylko, jak Tatarzy rozpuścili czambuły i przystapili do rabowania całej okolicy. Na szczęście nie trwało to długo, gdyż do dowódców tej łupieżczej wyprawy dotarła fałszywa wiadomość, że książę Adam Konstanty Ostrogski zgromadził w Tarnopolu wielkie wojska i ruszył na odsiecz bratu, zmierzając do odcięcia im drogi odwrotu. Obawiając się konieczności podjęcia walki z ludźmi obu książąt,

10 Por. Z. Anusik, Glosa..., s. 177-179; idem, $Z$ dziejów..., s. 459-461; J. Długosz, Podział latyfundium Ostrogskich w roku 1621, „Acta Universitatis Wratislaviensis" nr 8, Historia XVI, 1969, s. 3-15.

11 Por. Wyciagi z summaryusza..., s. 219, 224, 272, 589, 598.

12 Por. W. Nekanda Trepka, Liber generationis plebeanorum („Liber chamorum”), wyd. W. Dworzaczek, J. Bartyś, Z. Kuchowicz, red. W. Dworzaczek, cz. 1 (Wstępy wydawców i tekst), Wrocław-Warszawa-Kraków 1963, nr 314, 605, 788, $1178,1271$. 
Tatarzy po kilku dniach rabunków, w wyniku których ucierpiały przede wszystkim dobra Ostrogskich, wycofali się $z$ Wołynia ${ }^{13}$.

Nie zdobywszy na razie oczekiwanych laurów wojennych, Janusz Paweł ks. Ostrogski osiągnął sukces na innym polu, okazując się bardzo zręcznym graczem sejmikowym. Jego aktywność w tym zakresie zwiazana była $z$ zadawnionymi sporami, jakie wdowa po Aleksandrze ks. Ostrogskim i jego synowie wiedli $z$ jego starszym bratem, kasztelanem krakowskim Januszem. Ten ostatni, niezadowolony z aktu podziałowego z 1603 r., toczył ze szwagierką i bratankami spory o granice dóbr i zgłaszał pretensje do części majątków przyznanych niegdyś wojewodzie wołyńskiemu. Kościa niezgody było również zagarnięcie przez pana krakowskiego starostwa perejasławskiego na Zadnieprzu, które po śmierci księcia Aleksandra obją (aczkolwiek chyba bez tytułu prawnego) jego najstarszy syn ${ }^{14}$. Szykując się do procesu w Trybunale Koronnym w 1618 r., zarówno kasztelan krakowski, jak i jego bratankowie starali się o wybór przychylnych sobie sędziów. Janusz Paweł ks. Ostrogski we wrześniu 1617 r. przybył osobiście na sejmik deputacki województwa wołyńskiego we Włodzimierzu. Stawił się tu również wojewoda bracławski Aleksander ks. Zasławski, który reprezentował interesy swojego teścia, kasztelana krakowskiego Janusza ks. Ostrogskie-

${ }^{13}$ Por. S. Kardaszewicz, op. cit., s. 45-46; J. Wolff, op. cit., s. 358 (tu, nawiązująca bez wątpienia do opisanego wyżej wydarzenia informacja, że Adam Konstanty ks. Ostrogski odznaczył się w walkach $z$ Tatarami pod Tarnopolem).

${ }^{14}$ Sprawa starostwa perejasławskiego nie jest jednoznaczna. Zdaniem Henryka Litwina po śmierci Aleksandra ks. Ostrogskiego przywilej na tę dzierżawę (jeszcze w 1603 r.) otrzymał jego najstarszy syn, Adam Konstanty (wówczas siedmioletni). Starostwem administrował więc w jego imieniu stryj, kasztelan krakowski Janusz, który sam wystarał się o przywilej na Perejasław w 1604 r., a formalnie przejął tę królewszczyznę dopiero po śmierci bratanka w $1618 \mathrm{r}$. Por. idem, Napływ szlachty polskiej na Ukraine 1569-1648, Warszawa 2000, s. 191. Problem polega jednak na tym, że w Metryce Koronnej nie odnotowano nadania Perejasławia ani na rzecz Adama Konstantego, ani też na rzecz Janusza. W moim przekonaniu po śmierci wojewody wołyńskiego Ostrogscy władali tą królewszczyzna bez jakiegokolwiek tytułu prawnego, a w kancelarii królewskiej zaakceptowano ten stan rzeczy. Przynajmniej do 1613 r. za starostę perejasławskiego uważano najstarszego $z$ wojewodziców wołyńskich. Od 1615 r. zarówno pod względem formalnym, jak i faktycznym starostwo przeją jednak kasztelan krakowski i zatrzymał je w swoich rękach do końca życia. Por. Wyciagi z summaryusza..., s. 200 (tu Perejasław jako dzierżawa w rękach Adam Konstantego ks. Ostrogskiego), 265, 277 (tu Perejasław w rękach Janusza ks. Ostrogskiego); A. Boniecki, op. cit., s. 238; A. J akowe nko, op. cit., s. 123 (tu kasztelan krakowski jako starosta perejasławski w latach 1604-1620). 
go. W trakcie trwania obrad sejmiku okazało się, że młody Ostrogski dysponuje tak znaczacym poparciem miejscowej szlachty, że zaraz na wstępie udało mu się zrównoważyć wpływy starej fakcji pana krakowskiego. Dodatkowo kniaź Janusz Paweł ściagnął do Włodzimierza tłumy drobnej szlachty ze swoich dóbr położonych za Horyniem oraz znaczną rzeszę klientów. Kiedy zaś jego sprawę poparli obecni we Włodzimierzu Albrycht Stanisław ks. Radziwiłł, Jerzy ks. Czartoryski i Adam Aleksander ks. Sanguszko, szala zwycięstwa przechyliła się zdecydowanie na jego korzyść. Żaden $z$ kandydatów popieranych przez jego stryja nie został wybrany deputatem do Trybunału Koronnego. Sacdzić natomiast można, że wśród sześciu zwycięzców tej elekcji znaleźli się też ludzie związani $z$ fakcja młodych Ostrogskich ${ }^{15}$.

W tym samym czasie poczet młodych książąt stawił się w obozie wojsk koronnych pod Busza, gdzie po krótkich rokowaniach, 23 września 1617 r. hetman Stanisław Żółkiewski zawarł mocno krytykowany przez współczesnych traktat $z$ Turkami ${ }^{16}$. Bracia Ostrogscy byli bez watpienia lubiani i popularni na Wołyniu. W styczniu 1618 r. obaj zostali wybrani posłami na sejmiku przedsejmowym w Łucku. Wzięli też udział w burzliwych obradach sejmu, który zebrał się w Warszawie 13 lutego i obradował do końca marca tego roku. Młodzi książęta nie zapisali się wówczas niczym szczególnym, ale nawiązali bliższe stosunki $z$ późniejszym mężem ich siostry Katarzyny Tomaszem Zamoyskim. W drodze powrotnej do domu Ostrogscy zatrzymali się w Lublinie, gdzie po krótkiej chorobie, 10 kwietnia 1618 r. zmarł książę Adam Konstanty. Janusz Paweł odwiózł ciało brata do Jarosławia, gdzie 7 czerwca

15 Por. K. Mazur, W strone integracji z Korona. Sejmiki Wołynia i Ukrainy $w$ latach 1569-1648, Warszawa 2006, s. 154-157 (tu jednak pozbawione jakichkolwiek racjonalnych podstaw przypuszczenie, że w Trybunale Koronnym miano rozstrzygać kwestię przejęcia przez kasztelana krakowskiego całego latyfundium Ostrogskich, czyli wydziedziczenia jego bratanków!). Gwoli wyjaśnienia dodajmy więc, że najważniejszą sprawą interesująca wówczas obie zwaśnione strony był proces o dobra Suraż na Wołyniu, od 1603 r. stanowiące własność młodych Ostrogskich, która to majętność usiłował odebrać im pan krakowski. Por. P. Gawłowski do Janusza ks. Ostrogskiego, Przemyśl 16 XI 1618, Archiwum Główne Akt Dawnych w Warszawie [dalej: AGAD], Archiwum Potockich z Łańcuta [dalej: APŁ], Korespondencja Ostrogskich, nr 1532 (tu streszczenie niekorzystnego dla kasztelana krakowskiego dekretu Trybunału Koronnego w sprawie o Suraż).

${ }^{16}$ Por. Pisma Stanisława Żółkiewskiego kanclerza i hetmana, wyd. A. Bielowski, Lwów 1861, s. 306. 
wyprawiono zmarłemu księciu uroczysty pogrzeb ${ }^{17}$. W tym samym miesiącu rozstrzygnęła się również sprawa dziedziczenia dóbr po kasztelanie krakowskim. W 1609 r. sejm zezwolił księciu Januszowi Ostrogskiemu na utworzenie ordynacji rodu Ostrogskich pod warunkiem, że jej statut zostanie wpisany do akt Trybunału Koronnego w Lublinie. Pan krakowski zwlekał jednak $z$ wypełnieniem tego zobowiązania. Początkowo liczył na to, że uda mu się dojść do porozumienia $z$ bratankami, którzy wydawali się naturalnymi kandydatami do objęcia projektowanego majoratu. Nadzieje te jednak zawiodły. Co więcej, 23 kwietnia 1617 r. trzecia żona księcia Janusza, Teofila Tarłówna, urodziła mu upragnionego syna, Janusza Włodzimierza. Można przypuszczać, że gdyby przeżył on ojca, ordynacja ostrogska nigdy by nie powstała. Dziecko zmarło jednak już 11 stycznia 1618 r. W tej sytuacji pan krakowski zdecydował się sfinalizować odkładaną od kilku lat sprawę i 22 czerwca tego roku podał do akt trybunalskich statut i szczegółowe rozporządzenia dotyczace dziedziczenia ordynacji. Książę Janusz Paweł Ostrogski został oddalony od sukcesji, a utworzony przez jego stryja majorat miał być dziedziczony przez męskich potomków córki kasztelana krakowskiego, Eufrozyny z Ostrogskich ks. Zasławskiej (pierwszym ordynatem został w 1620 r. najstarszy wnuk księcia Janusza, Franciszek ks. Zasławski) ${ }^{18}$.

We wrześniu 1618 r. Janusz Paweł ks. Ostrogski, który po śmierci brata stał się jedynym dziedzicem ogromnego latyfundium młodszej linii tego książęcego domu, zjawił się ze swoimi oddziałami pod Oryninem, gdzie hetman wielki koronny Stanisław Żółkiewski zamierzał odeprzeć spodziewane uderzenie wojsk tatarskich. Ludzie Ostrogskiego stanęli obozem obok innych obozów magnackich, na prawo od usytuowanego w centrum obozu wojsk kwarcia-

17 Por. K. Mazur, op. cit., s. 162, 415; J. Seredyka, Sejm 1618 roku, Opole 1988; W. Dobrowolska, Książęta Zbarascy w walce z hetmanem Źótkiewskim, Kraków 1930, s. 19-25; Z. O s s olińs ki, op. cit., s. 102-107; S. Żu rkows ki, Żywot Tomasza Zamojskiego, kanclerza w. kor., wyd. A. Batowski, Lwów 1860, s. 33-34; S. Kardaszewicz, op. cit., s. 47; J. Śliwski, Na Iasnie oświeconego Adama Constantego Xiążecia Ostrogskiego woiewodzica wołyńskiego żałosny pogrzeb kazanie... w Jarosławiu, na dzień 7 czerwca zgotowane, Kraków 1618; N. Jakowenko, Druga strona lustra. $Z$ historii wyobrażen i idei na Ukrainie XVI-XVII wieku, Warszawa 2010, s. 286, 297-298.

18 Por. A. Boniecki, op. cit., s. 238-239; S. Kardaszewicz, op. cit., s. 218-219; Z. Os soliński, op. cit., s. 100; Wyciagi z summaryusza..., s. 299; Z. Anusik, Glosa..., s. 196-199; idem, Z dziejów..., s. 479-481; T. Chynczews ka-He nn el, Ostrogski Janusz, [w:] PSB, t. XXIV, s. 485. 
nych. Na lewej flance bardzo rozciagniętego szyku wojsk polskich zatoczono $z$ kolei odosobniony obóz wojewody podolskiego Tomasza Zamoyskiego, który przyprowadził 1200 własnych żołnierzy. W obozie tego ostatniego stanęli również ludzie nieobecnego pod Oryninem kasztelana krakowskiego Janusza ks. Ostrogskiego, dowodzeni przez kasztelana żarnowskiego Jana Gratusa Tarnowskiego, oraz 400-osobowy oddział dziadka Tomasza Zamoyskiego, kasztelana sandomierskiego Stanisława Tarnowskiego. Nie dość, że się te wszystkie obozy „rozwlekły jako przez wszystek Kleparz, Kraków, Stradom i Kazimierz", że kresowi magnaci nie zamierzali iść pod komendę hetmana, to jeszcze Polacy dali się zaskoczyć Tatarom. Dopiero 28 września, pół godziny przed ich nadejściem, Źółkiewski dowiedział się bowiem, że są oni już bardzo blisko. Tego samego dnia, około godziny 15.00 murza Kantymir natarł na najsłabszy punkt polskich stanowisk, czyli na obóz Zamoyskiego. Tatarzy kilkakrotnie ponawiali atak (w sumie obrońcy odparli dziewięć szturmów) i tylko ogień $z$ dział i rusznic piechoty wojewody podolskiego powstrzymywał wroga. Położenie obrońców stało się jednak naprawdę groźne, kiedy pod wieczór ze znacznie już większymi siłami uderzył na nich Sołtan Gałga. Tymczasem tak Żółkiewski, jak i pozostali magnaci zachowali całkowitą bierność, obserwując tylko $z$ daleka przebieg tego starcia i nie podejmując nawet próby wyprowadzenia swoich oddziałów $z$ umocnionych obozów i stoczenia otwartej bitwy. Kiedy już wydawało się, że Tatarzy złamią opór obrońców atakowanego obozu, koniuszy koronny Krzysztof ks. Zbaraski wysłał na pomoc Zamoyskiemu 200 swoich konnych strzelców w zbrojach, którzy pomogli „bardzo dobrze, ale też i samych kilkunastu ubito". Później i sam hetman podesłał Zamoyskiemu dwie choragwie husarskie bez kopii, ale nastapiło to w chwili, kiedy Tatarzy rozpoczęli odwrót i ,już te roty hetmańskie żadnej pomocy nie dały". Najgorsze miało jednak dopiero nastapić. Noca Tatarzy ominęli bowiem stanowiska wojsk polskich i rozpuścili zagony aż po Tarnopol i Lwów na Rusi Czerwonej oraz Dubno i Zasław na Wołyniu, paląc miasta i wsie oraz uprowadzając ogromny jasyr. Dopiero po południu następnego dnia Polacy zorientowali się, że nieprzyjaciel gdzieś odszedł. Zamiast jednak ruszyć za nim w pościg, przez kilka dni siedzieli bezczynnie w obozie. Zgromadziwszy pod Oryninem kilkanaście tysięcy żołnierzy, zarówno hetman Stanisław Żółkiewski, jak i skłóceni $z$ nim magnaci kresowi, na których również spada odpowiedzialność za tę haniebną kam- 
panię, dopuścili w rezultacie do tego, że po zakończeniu swojego łupieżczego procederu nieprzyjaciel „przeszedł bezpiecznie, broni dobytej przed sobą nie widzac, Czarnym Szlakiem do domu swego"19.

W roku następnym Janusz Paweł ks. Ostrogski postanowił się ożenić. Jego wybranka była Izabela Daniłowiczówna, córka Mikołaja, podskarbiego wielkiego koronnego, oraz Heleny z Uchańskich, wojewodzianki bełskiej. O rękę tej samej panny starał się również Jerzy Ossoliński, w przyszłości kanclerz wielki koronny, który 26 lipca 1619 r. w towarzystwie stryja i jednego ze starszych braci pojawił się w domu podskarbiego. Po latach Ossoliński tak oto wspominał swoje ówczesne konkury: „Janusz, książę Ostrogski, usłyszawszy o przymiotach rzadkich i wychowaniu świątobliwym tej panienki, za perswazyja stryjenki swojej, paniej krakowskiej, $z$ domu Tarłównej, obrócieł się $z$ staraniem swoim w dom pana podskarbiego i pod tenże właśnie czas miał przyjechać na stanowienie małżeństwa tego, by go była choroba w Lublinie nie zatrzymała. Przyjechałem ja, nic o tym nie wiedzac, do Uchan na czas naznaczony, skromnie, ale przystojnie rzemyka pociagając [...] Przyjęto nas wdzięcznie, ale rezolucyjej obiecanej nie dano, pięknymi słowy się wymówiwszy i do innego czasu odłożywszy dlatego, aby tymczasem Ostrogski nadjechał. Ale że Pan Bóg mnie, ubogiemu pachołkowi, nie książęciu, gotował przyjaciela i pociechę, łacno $i$ ten impedyment uprzątnąl, wziąwszy go $z$ tego świata $w$ ten sam właśnie dzień, kiedym ja $z$ Uchań wyjechawszy, przez Lublin jachał; tamem ja dopiero o tak potężnym dowiedział się konkurencie i za wielka opatrzność bożą jego świętemu majestatowi podziękował"20.

Książę Janusz Paweł, podobnie jak jego zmarły wcześniej brat, chorował na kiłę. Obaj bracia mieli też opinię rozpustników nadużywajacych uciech cielesnych. Nie wahali się też łamać obowią-

19 Por. Stanisław Tarnowski do Zbigniewa Ossolińskiego, Zinków 8 X 1618, H. Malewska, Listy staropolskie $z$ epoki Wazów, Warszawa 1959, s. 163-171; Z. Os soliński, op. cit., s. 109-112; S. Żurkowski, op. cit., s. 35-39; W. Dobrowols ka, op. cit., s. 29-31; W. Dw or zacze k, Hetman Jan Tarnowski. Z dziejów możnowładztwa małopolskiego, Warszawa 1985, s. 418-420. W tym miejscu wypada tylko dodać, że pojawiajacca się w literaturze przedmiotu informacja, jakoby Janusz Paweł ks. Ostrogski wysłał swoich ludzi na pomoc odpierajacemu ataki Tatarów na swój obóz Tomaszowi Zamoyskiemu, nie znajduje potwierdzenia źródłowego.

20 J. Ossoliński, Pamiętnik, oprac. W. Czapliński, Warszawa 1976, s. 90. Por. też Z. Anusik, Glosa..., s. 176; oraz idem, $Z$ dziejów..., s. 458-459. Dodajmy w tym miejscu, że po zgonie księcia Janusza Pawła Ostrogskiego podskarbi Daniłowicz zdecydował się oddać rękę córki Jerzemu Ossolińskiemu. 
zujących powszechnie konwenansów. O jednej z ich nietypowych rozrywek wspomina Kasper Niesiecki: „Jeden $z$ nich do reflektarza zakonnego przyszedłszy, żywoty świętych na celu sobie postawiwszy głęboko ich strzała przeszył; słowo na którem się strzała oparła, było śmierć, zkąd prędkiej się dla niego obawiano zguby, jakoż i była" ${ }^{21}$. O złej opinii młodych książąt wśród współczesnych świadczy też sprzeczka między Januszem Pawłem a Adamem Aleksandrem ks. Sanguszką, któremu Ostrogski musiał ustąpić wyższego miejsca na sejmiku deputackim we Włodzimierzu we wrześniu 1617 r. Wojewodzic wołyński, nawiązując do tego, że jego adwersarz najpierw wstapił do klasztoru, a później porzucił życie zakonne i zawarł związek małżeński, zwrócił się do niego następującymi słowami: „Jeśli Wasza Ksiażęca Mość pretendujesz starsze miejsce, żeś się ożenił, mogę się ja ożenić, albo też zaś być mnichem". W odpowiedzi doczekał się ciętej riposty ze strony Sanguszki: „Żona tu albo ożenienie [nie] mają tu czynić, a tego się nie wstydzę, żem w bojaźni Bożej prowadził wiek młody, a nie dissolute jak WM"22. O rozpuście młodych książąt Ostrogskich, będącej jakoby przyczyna ich przedwczesnej śmierci, pisał także dobrze poinformowany Joachim Jerlicz ${ }^{23}$. W rzeczywistości jednak, jak wspomniano, obaj wojewodzice wołyńscy zmarli w wyniku powikłań chorobowych, do jakich w ich przypadku doprowadziła nieleczona lub też źle leczona kiła.

Złożony śmiertelną chorobą, Janusz Paweł ks. Ostrogski sporządził w dniu swojej śmierci, 6 sierpnia 1619 r. w Lublinie akt swojej ostatniej woli (cały tekst w aneksie) ${ }^{24}$. Jest to w sumie dość

${ }^{21}$ K. Nie sie cki, Herbarz polski, wyd. J.N. Bobrowicz, t. VII, Lipsk 1841, s. 189.

$22 \mathrm{O}$ przywołanym tu spięciu młodego kniazia Ostrogskiego z Sanguszka informował w lutym 1618 r. kasztelana krakowskiego Janusza ks. Ostrogskiego jego zięć, wojewoda bracławski Aleksander ks. Zasławski. Por. K. Mazu r, op. cit., s. 96-97. Por. też W. Kłaczewski, Sanguszko Adam Aleksander, [w:] PSB, t. XXXIV, Wrocław 1992-1993, s. 464.

${ }^{23}$ Por. J. Jerlicz, op. cit., t. I, s. 33. Por. też Z. Ku chowicz, Człowiek polskiego baroku, Łódź 1992, s. 115, 122, 235; oraz A. Rolle, O dziedziczności obłąkania, „Przeglą Lekarski: Organ Towarzystw Lekarskich Krakowskiego i Galicyjskiego” 1889, nr 5, s. 61 (tu, oparta jednak na zbyt watłych przesłankach źródłowych, próba udowodnienia, że Adam Konstanty i Janusz Paweł ks. Ostrogscy cierpieli na zaburzenia psychiczne).

${ }^{24}$ Warto w tym miejscu odnotować, że testament młodszego $z$ braci Ostrogskich był już dwukrotnie ogłaszany drukiem. Po raz pierwszy opublikował go J. Makara, przy czym podstawa tej edycji była kopia przechowywana w Archiwum Archidiecezjalnym w Przemyślu. Por. idem, Dzieje parafii jarosławskiej od poczatku do r. 1772, Jarosław 1936, s. 126-128. Po raz drugi akt ostatniej 
typowy testament $z$ tej epoki. Wyróżnia go jednak to, że ogromną większość tekstu zajmują różnego rodzaju legaty. Instytucjom kościelnym zapisał książę 2 wsie i 5500 zł. Zdecydowanie więcej otrzymali natomiast jego dworzanie. Siedmiu najznaczniejszym legował dożywocie na 11 wioskach. Każdy z nich otrzymał również dodatkowo $5000 \mathrm{zł}$. Trzem kolejnym zapisał po 1000, a jednemu 700 zł. W dodatkowym zapisie książę Janusz Paweł podarował czterem dworzanom pominiętym w pierwszej części testamentu po $10000 \mathrm{zł}$. W sumie zatem 15 wymienionych imiennie sług i klientów umierajacego kniazia otrzymało legaty na kwotę $78700 \mathrm{zl}$. Wartość pozostałych zapisów dokonanych przez Janusza Pawła ks. Ostrogskiego jest trudna do oszacowania. Książę nakazał bowiem zwrócić wszystkim cerkwiom w swoich dobrach zajęte wcześniej mienie. Sługom „młodszym”, których liczby niestety nie znamy, zapisał po 500 zł. Największym obciążeniem pozostawionego przez niego majątku było jednak, jak się wydaje, rozporządzenie, na mocy którego wszyscy dzierżawcy dóbr książęcych, którzy pozostawali niegdyś w służbie księcia Adama Konstantego lub też służyli samemu księciu Januszowi Pawłowi, otrzymali dożywocie na trzymanych przez siebie wioskach. Każdy $z$ nich otrzymał również dodatkowo $5000 \mathrm{zl}$, w której to sumie miał trzymać dzierżawione dotychczas dobra modo obligatorio. Jak się wydaje, przy bardzo ostrożnym szacunku, wartość hojnych zapisów dokonanych przez ostatniego męskiego przedstawiciela młodszej linii domu książąt Ostrogskich przekraczała roczny dochód $z$ jego latyfundium, czyli sumę 200 tys. zł.

woli Janusza Pawła wydał J. Ku s. Por. id e m, Testament księcia Janusza Pawła Ostrogskiego z 1619 r., „Zeszyty Muzealne. Muzeum w Jarosławiu” 1997/1998, R. II, z. 2, s. 19-21, 116-119. Zaletą tej z kolei edycji źródłowej jest bez wątpienia fakt, że autor uzupełnił informacje zawarte we wpisie do ksiag grodzkich lubelskich o wpis $z$ księgi czynności publicznych prowadzonej przez spisującego testament, notariusza publicznego Sebastiana Kajka z Sulmierzyc, przechowywanej do dziś w Archiwum Archidiecezjalnym w Lublinie. Na podstawie tego wpisu możemy stwierdzić, że należący do Ludwika i Anny Poniatowskich dwór, w którym zmarł książę Janusz Paweł, był położony nieopodal kolegium jezuitów, w rejonie obecnych ulic Królewskiej i Żmigrodu. Wiemy też, że ostatnie godziny swego życia spędził młody magnat w sklepionej izbie, której okna wychodziły na miasto. $Z$ informacji zanotowanych przez notariusza wynika również, że osłabiony choroba książę, swoją ostatnią wolę dyktował z przerwami. Zasadniczą część zaczął dyktować o godzinie 9.00. Godzinę później, gdy „trochę sobie odpoczął”, podyktował drugą część testamentu. Wreszcie około 13.00 została spisana jego ostatnia część, która podpisał już tylko notariusz. Godzinę później Janusz Paweł ks. Ostrogski już nie żył. Por. ibidem, s. 19-20. 
Trudno powiedzieć, na ile treść tego dokumentu była zgodna z rzeczywista wola testatora. Wattpliwości budzi bowiem zarówno jego struktura, jak i fakt, że został on oblatowany w grodzie lubelskim przez grupę 13 domowników zmarłego księcia dopiero 22 sierpnia 1619 r., a zatem 15 dni po jego sporządzeniu ${ }^{25}$. Już współcześni wyrażali wątpliwość co do autentyczności tego aktu. Mieszkający w położonych niedaleko Lublina Jakubowicach Murowanych Jerzy Klimoszewicz, sługa kasztelana krakowskiego Janusza ks. Ostrogskiego, już 2 września 1619 r. informował swojego pryncypała o machinacjach przy testamencie jego zmarłego bratanka. Donosił też o rabunkach ruchomości pozostałych po kniaziu Januszu Pawle, jakich dopuszczali się jego słudzy w Ostrogu i w innych miejscach. O zagarnięcie pieniędzy, szat, kobierców i klejnotów należących niegdyś do księcia Janusza Pawła oskarżał też jednego $z$ jego plebejskich domowników Walerian Nekanda Trepka ${ }^{26}$. Ciało zmarłego księcia przewieziono $z$ Lublina do Jarosławia, gdzie 29 października wyprawiono mu uroczysty pogrzeb. Spoczął on w kaplicy fary jarosławskiej obok swojego starszego brata Adama Konstantego ${ }^{27}$.

Edytowany dokument opracowano zgodnie $z$ zaleceniami instrukcji wydawniczej Kazimierza Lepszego ${ }^{28}$, z pewnymi jednak, niewielkimi modyfikacjami. Zgodnie $z$ dominująca ostatnio tendencją $w$ tego typu wydawnictwach nie dokonano pełnej modernizacji pisowni wyrazów staropolskich, zachowujac ich cechy językowe. W związku $z$ tym bez zmian pozostawiono końcówki: ej, em, emi, ie, ję, jak również pisownię liczebników. Nie zmieniano również litery „ę" na „a”, jak wypadałoby to zrobić zgodnie $z$ zasadami współczesnej ortografii. Samogłoski „y” oraz „i” oddano zgodnie $z$ obecnie

25 Por. Oblata testamentu księcia Janusza Ostrogskiego, Archiwum Państwowe w Lublinie, Lubelskie grodzkie, Relacje, nr 49, k. 770-772.

${ }^{26}$ Por. J. Klimoszewicz do J. Ostrogskiego, Jakubowice 2 IX 1619, AGAD, APŁ, Korespondencja Ostrogskich, nr 1544; W. Nekanda Trepka, op. cit., nr 788. W sprawie niejasnych okoliczności śmierci księcia Janusza Pawła por. też J. Ku s, „Wielkie...”, s. 16.

${ }_{27}$ Por. Pietas in ilustrissimum Dominum Janussium Paulum Ducem in Ostrog etc. a nobili iuventute Collegii Kostkoviani SJ brevi threnodia Jaroslaviae mense Domitiani exhibita, Zamosci 1619; N. Jakowenko, Druga strona..., s. 297-298; J. Ku s, „Wielkie...”, s. 14.

28 Instrukcja wydawnicza dla źródeł historycznych od XVI do połowy XIX wieku, red. K. Lepszy, Wrocław 1953. 
obowiązującymi regułami. Słowo „wszitko” zapisano jako „wszytko”. Podwójne głoski „ss” zastapiono pojedynczymi. Uzupełniono pomijane w tekście litery diakryzowane, takie jak „a”, „ć”, „ę", „”,

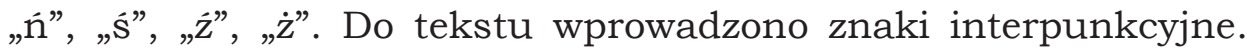
Dokonano modernizacji pisowni wszystkich imion, nazwisk i nazw miejscowych. Wielkich i małych liter użyto zgodnie ze współczesnymi zasadami. Rozwinięto wszystkie abrewiacje, rozwiązano skróty, uzupełniono pominięte przez pisarza litery, jak również zamieszczono tłumaczenia wyrazów i zwrotów łacińskich. W nawiasach kwadratowych zaznaczono poczatek nowej strony $\mathrm{w}$ oryginale. W przypisach tekstowych zamieszczono uwagi odnoszace się do postaci zewnętrznej i brzmienia podstawy źródłowej. W przypisach rzeczowych w miarę możliwości starano się zidentyfikować występujące w tekście postaci i nazwy miejscowe.

\section{ANEKS}

Or.: Archiwum Państwowe w Lublinie, Grodzkie lubelskie, Relacje, nr 49, k. 770-772 (oblata 22 sierpnia 1619 r.); po śmierci testatora do akt podali domownicy zmarłego: Jan Bądzyński, miecznik województwa wołyńskiego, Kacper Brodowski ${ }^{29}$, Stanisław Bądzyński, Mikołaj Głębocki ${ }^{30}$, Ludwik Poniatowski, Stefan Wojnarowski, Adam Jordan, Adam Bojanowski, Gabriel Remczycki, Stanisław Broniowski, Annibal Monty (Monti), Jerzy Kruszyński i Stanisław Przytycki ${ }^{31}$. Odnotowano również, że testament został spisany własnoręcznie przez notariusza publicznego Sebastiana Kajka.

[k. 770v] W imię Ojca, Syna i Ducha Świętego, Boga w Trójcy Jedynego Amen.

${ }^{29}$ Kasper Brodowski h. Łada zm. 1627, syn Mikołaja, później, w latach 16251627 podczaszy chełmski. Por. A. B o n i e cki, Herbarz polski, t. II, Warszawa 1900, s. 127; Urzędnicy województw bełskiego i ziemi chełmskiej XIV-XVIII wieku. Spisy, oprac. H. Gmiterek, R, Szczygieł, red. A. Gassiorowski, Kórnik 1992, nr 1240.

${ }^{30}$ Mikołaj Głębocki zapewne h. Doliwa, później podstoli lwowski, dzierżawca królewskiej wsi Zachurze. Por. AGAD, Metryka Koronna 182, k. 246v-247.

${ }^{31}$ Stanisław Badzyński był zapewne krewnym miecznika wołyńskiego Jana i pieczętował się herbem Junosza, podobnie jak Adam Bojanowski. Nic więcej na ich temat nie wiadomo. Postacią bliżej mi nieznana jest również Stanisław Przytycki. Informacje o pozostałych domownikach księcia Janusza Pawła Ostrogskiego oblatujących jego testament por. niżej w kolejnych przypisach. 
Schodzac $z$ tego świata, ten testament ostatniej wolej swojej zostawuję, powierzając sumieniom ${ }^{a}$ potomków moich ${ }^{32}$, aby on we wszytkich punktach wcale zachowali i wykonali.

Naprzód ducha mego Panu Bogu w ręce oddaję, prosząc Jego Świętobliwego Majestatu, aby mnie nie wedle wielkości grzechów moich, ale wedle swego nieprzebranego miłosierdzia sądzić raczył.

Ciało moje w kościele jarosławskiem, w kaplicy u fary, tam gdzie brat mój najmilszy pobożnej pamięci książę Konstanty Ostrogskie w Panu Bogu odpoczywa ${ }^{33}$, ma być pochowane.

Kościołom greckiem ${ }^{34}$ cokolwiek należy i na co prawo pokażą, ma być wszytko przywrócone i do posesji puszczone.

Do kościoła łacińskiego ostrogskiego, gdzie sławnej pamięci Książę Jegomość Pan Konstanty, pan stryj mój leży ${ }^{35}$, leguję i wiecznemi czasy daruję wieś w ostrogskiej włości leżącą Moszczenicę ${ }^{36}$ $z$ tą obligacja, żeby pięciu wikariuszy ${ }^{\mathrm{b}}$ a szósty proboszcz za duszę moję dwakroć msza w tydzień odprawowali feria secunda et sexta requiem et die sabbati de Beata Virgine atque feria teria sacrum cantatum.

Do kaplicy kościoła farnego jarosławskiego, gdzie ciało moje pochowane będzie, wieś Nowosielce ${ }^{37}$ od klucza przeworskiego, na której wyderkaf jest zapisany, funduję wiecznemi czasy.

a W źródle: „sumnieniom”.

b W źródle: „wikariów”.

${ }^{32}$ W tym przypadku w znaczeniu „spadkobierców”, gdyż książę był kawalerem i zmarł bezpotomnie.

${ }^{33}$ Kaplica pw. św. Stanisława przy kolegiacie w Jarosławiu, gdzie pochowano starszego brata testatora, Adama Konstantego ks. Ostrogskiego.

${ }^{34}$ Chodzi tu o cerkwie prawosławne (dyzunickie) w dobrach testatora.

${ }^{35}$ Kościół farny w Ostrogu pw. Matki Bożej ufundowany został w XV w. przez kniazia Fedora Daniłowicza Ostrogskiego. Odnowił go w 1582 r. wojewoda kijowski Konstanty Wasyl ks. Ostrogski. Został tu pochowany, zmarły w 1588 r. średni syn wojewody kijowskiego, krajczy litewski i starosta włodzimierski Konstanty ks. Ostrogski. Por. S. Kardaszewicz, op. cit., s. 42.

${ }^{36}$ Moszczenica, wieś na Wołyniu w powiecie łuckim, położona około $17 \mathrm{~km}$ na północny wschód od Ostroga.

37 Nowosielce, wieś w ziemi przemyskiej w województwie ruskim, położona w odległości około $7 \mathrm{~km}$ na zachód od Przeworska. Dla uczczenia pamięci starszego brata 15 maja 1619 r. Janusz Paweł ks. Ostrogski ufundował przy kaplicy pw. św. Stanisława mansjonarię, uposażając jej prepozyta i pięciu kapłanów sumą 1200 zł rocznie od kwoty kapitałowej 17143 zł zapisanej na wyderkaf na tej właśnie wiosce. Por. J. Ku s, „Wielkie...”, s. 12. 
Ojcom karmelitom ${ }^{c}$ lubelskiem leguję dwa tysiące złotych.

Księżnom Ichmościom ${ }^{38}$ wszytko przypadnie jako sukcesorkom.

Ojcom jezuitom jarosławskiem tysiąc złotych.

Mniszkom jarosławskiem ${ }^{39}$ tysiąc złotych.

[k. 771] Sługom swoim wszytkim i nieboszczykowskiem także $\mathrm{e}^{40}$, którzy majętności trzymaja, po piąci tysięcy złotych na tych dzierżawach modo obligatorio zapisuję i dożywocia.

P. Moszyńskiemu ${ }^{41}$, że nie ma nic, zapisuję na Zalasowej, Złotyczówce, Korytach pięć tysięcy złotych, co ma trzymać aż do wykupna pospołu wszytko i dożywocie ${ }^{42}$.

P. Broniowskiemu ${ }^{43}$ na Wierzchosławicach ${ }^{44}$ pięć tysięcy złotych i dożywocie, co sobie ma wykupić od Pana Szumowskiego i we dwojgu sumach trzymać.

" W tekście: „karmelitanom”.

38 Mowa tu o siostrach księcia Janusza Pawła - Zofii, żonie Stanisława Lubomirskiego, Katarzynie, od 1620 r. żonie Tomasza Zamoyskiego i Annie Alojzie, w 1620 r. wydanej za Jana Karola Chodkiewicza.

${ }^{39}$ Chodzi tu o klasztor benedyktynek w Jarosławiu.

40 Testator wspomina tu o sługach swojego nieżyjaccego brata, Adama Konstantego ks. Ostrogskiego.

${ }^{41}$ Hieronim (Jarosz) Moszyński, jeden ze świadków testamentu księcia Janusza Pawła.

${ }^{42}$ Nie jest pewne, jakie wsie miał przejąć w dożywocie Hieronim Moszyński. Zalasowa, miejscowość w powiecie pilzneńskim województwa sandomierskiego, położona w odległości około $15 \mathrm{~km}$ na południowy wschód od Tarnowa, była co prawda wsią należąca do „hrabstwa tarnowskiego”, ale jej właścicielem był stryj testatora, kasztelan krakowski Janusz ks. Ostrogski. Dwie pozostałe wioski leżały powiecie łuckim na Wołyniu, gdzie Ostrogscy byli właścicielami m.in. wsi Koryto, położonej w odległości około $16 \mathrm{~km}$ na północ od Dubna. Z kolei „Złotyczówka” to być może wieś Zołociew położona w odległości około $2 \mathrm{~km}$ na północ od Równego. $Z$ cała pewnościa nie była to natomiast wieś Złotyjów (Zołotyjów) we włości stepańskiej, jak twierdzi J. Ku s. Por. id e m, Testament..., s. 117. Cała włość stepańska także należała bowiem do kasztelana krakowskiego.

${ }^{43}$ Stanisław Broniowski, zapewne jeden $z$ czterech synów Jerzego Firleja-Broniowskiego h. Lewart. Być może to właśnie on był mężem Elżbiety, córki Konrada Krupki-Przecławskiego. Por. A. B on iecki, Herbarz polski, t. II, Warszawa 1900, s. 137.

${ }^{44}$ Wierzchosławice, wieś $\mathrm{w}$ powiecie pilzneńskim, województwie sandomierskim, położona w odległości około $10 \mathrm{~km}$ na zachód od Tarnowa, wchodziły w skład klucza tarnowskiego. Po wykupieniu tej wioski z rak dotychczasowego posesora, Broniowski miałby na niej zastaw równy sumie wykupu powiększonej o $5000 \mathrm{z}$. 
P. Remczyckiemu ${ }^{45}$ na szynwaldzkiem wójtostwie ${ }^{46}$, przydając ośm chłopów, pięć tysięcy i dożywocie.

P. Starzyckiemu ${ }^{47}$ Krupiec i Hlinniki ${ }^{48}$, pięć tysięcy na tem i dożywocie.

P. Wojnarowskiemu ${ }^{49}$ na Borowicy i Wilii ${ }^{50}$ pięć tysięcy i dożywocie.

P. Annibalowi ${ }^{51}$ na Tynnem ${ }^{52}$ pięć tysięcy i dożywocie.

P. Niezwojowskiemu ${ }^{53}$ tysiąc złotych.

P. Kruszyńskiemu ${ }^{54}$ tysiąc złotych.

Jezuitom lubelskiem tysiąc złotych na dzwon.

Ojcom bernardynom i dominikanom lubelskiem obiema półtora tysiąca, co po półósma sta rozumieć się ma ${ }^{55}$.

${ }^{45}$ Gabriel Remczycki, skarbnik nadworny księcia Janusza Pawła. Por. J. M akara, op. cit., s. 129.

${ }^{46}$ Wójtostwo we wsi Szynwałd wchodzacej w skład klucza tarnowskiego, położonej około $5 \mathrm{~km}$ na północ od wspomnianej w przypisie 42 Zalasowej.

47 Zapewne Aleksander Starzycki. W 1629 r. zamiast wsi Krupiec i Hlinniki we włości ostrogskiej, trzymał wsie Chomiaków, Lisica i Perewołoka (razem 105 dymów) w tym samym kluczu. Wszystkie wspomniane tu wsie stanowiły własność Anny z ks. Ostrogskich Chodkiewiczowej, wojewodziny wileńskiej. Por. O. Baranowycz, Zaljudnennja wołyns'koho wojewodstwa $w$ perszij połowyni XVII st., Kyjiw 1930, s. 40.

${ }^{48}$ Krupiec, wieś w powiecie łuckim na Wołyniu, położona około $18 \mathrm{~km}$ na wschód od Ostroga. Hlinniki, wieś w tym samym powiecie, leżąca około $26 \mathrm{~km}$ na północny wschód od Ostroga.

49 Stefan Wojnarowski h. Strzemię, w 1629 r. posesor wsi Borowica Mała i Wilia (razem 55 dymów) we włości ostrogskiej, własności wojewodziny wileńskiej Anny z ks. Ostrogskich Chodkiewiczowej. Por. O. Bara nowycz, op. cit., s. 40.

${ }^{50}$ Borowica Mała, wieś w powiecie łuckim, leżąca około $24 \mathrm{~km}$ na południowy zachód od Ostroga. Wilia, wieś w tym samym powiecie, położona około $20 \mathrm{~km}$ na południowy zachód od Ostroga.

${ }^{51}$ Annibal Monty (Monti), jeden $z$ dworzan oblatujących testament księcia Janusza Pawła.

52 Tynne, wieś w powiecie łuckim, we włości rówieńskiej (położona około $2 \mathrm{~km}$ na zachód od Równego), później własności Tomasza i Katarzyny z ks. Ostrogskich Zamoyskich. W 1629 r. wioska ta (55 dymów) pozostawała w posesji Stanisława Ołtarzewskiego. Por. O. Baranowy cz, op. cit., s. 44.

53 Skądinąd nieznany.

54 Jerzy Kruszyński h. Pobóg, później rotmistrz i pułkownik królewski, poseł do Stambułu, podstoli kamieniecki w latach 1635-1648. Por. K. Niesiecki, op. cit., t. V, Lipsk 1840, s. 398.

55 Półósma sta, czyli siedemset pięćdziesiąt. 
Księdzu Grębińskiemu ${ }^{56}$ złotych siedmset.

Panu Grębińskiemu ${ }^{57}$ tysiąc złotych.

P. Obuchowskiemu ${ }^{58}$ Pianie od Krupy ${ }^{59}$, pięć tysięcy i dożywocie.

Sługom inszem młodszem po pięci set złotych.

[k. 771v] Janusz książę Ostrogskie ręką swą,

Jan Bądzinski, miecznik wołyński ${ }^{60}$,

Konstanty Chreptowicz ${ }^{61}$ ręką swą, Aleksander Wielhorski ${ }^{62}$ manu propria, Jarosz Moszyński ręką swą własna, Sebastian ${ }^{d}$ Kajek $^{63}$ manu propria.

P. Moszyńskiemu, jeśli naprzód naznaczonych majętności nie będzie chciał trzymać, tedy sumę gotową pięć tysięcy złotych polskich leguję, która potomkowie moi zarazem onemu zapłacić mają, a to miasto pierwszego legatum.

d W tekście: „Sebastianus”.

56 Jan Grębiński (zm. 1644), prepozyt kolegiaty jarosławskiej. Towarzyszył braciom Ostrogskim w ich peregrynacjach naukowych. Por. S. Starowolski, Monumenta Sarmatarum, Cracoviae 1655, s. 437-438; J. Ku s, Testament..., s. 21.

${ }^{57}$ Jakub Grębiński, burgrabia zamku jarosławskiego i dowódca nadwornej piechoty ks. Ostrogskich. Później w służbie Stanisława Lubomirskiego, któremu towarzyszył w walkach pod Chocimiem w 1621 r. Por. S. Starowolski, op. cit., s. 438; J. Ku s, Testament..., s. 21.

58 Nie udało się ustalić niczego na jego temat.

${ }^{59}$ Pianie i Krupa - wsie we włości żornowskiej, w powiecie łuckim na Wołyniu. Pierwsza leżała w odległości około $20 \mathrm{~km}$, a druga około $30 \mathrm{~km}$ na północny zachód od Dubna. W 1629 r. obie wsie, stanowiące własność Tomasza i Katarzyny $z$ ks. Ostrogskich Zamoyskich (w Pianiach 80, a w Krupie 89 dymów), trzymał Jan Falibowski. Por. O. Baranowycz, op. cit., s. 45.

${ }^{60}$ Jan Bązyński z Osieka h. Junosza (zm. 1642), syn Wojciecha, miecznik wołyński w latach 1610-1634, podkomorzy chełmski w latach 1634-1642. Por. A. Boniecki, Herbarz..., t. I, Warszawa 1899, s. 138; Urzędnicy wołyńscy XIV-XVIII wieku, oprac. M. Wolski, Kórnik 2007, nr 667; Urzędnicy województw betskiego..., nr 1272.

${ }^{61}$ Konstanty Chreptowicz Bohuryński h. Odrowąż (zm. 1645), syn Jana, stolnik kijowski w latach 1625-1645. Por. A. Boniecki, Herbarz..., t. III, Warszawa 1900 , s. 88 .

${ }^{62}$ Aleksander Wielhorski h. Kierdeja (zm. 1642), syn Romana, wojski łucki w latach 1625-1642. Por. Urzędnicy wołyńscy..., nr 398.

${ }^{63}$ Sebastian Kajek z Sulmierzyc, notariusz publiczny, wójt i ławnik lubelski, krewny sławnego poety Sebastiana Klonowica, któremu ufundował tablicę epitafijna w lubelskim kościele pod wezwaniem św. Michała. 
P. Remczyckiemu i P. Broniowskiemu, jeśliby koronnemi majętnościami kontentować się nie chcieli, którem onem naznaczył, tedy onem potomkowie moi bona equivaletia na Wołyniu pod Ostrogiem na miejsce tych koronnych naznaczyć maja, które temże prawem jako koronne zastawą i dożywociem trzymać będą.

Janusz książę Ostrogskie

Księżnę Jejmość czyni opiekunką

Potem, ante horam undecimam, gdy słudzy Księcia Jegomości niektórzy przypomnieli P. Szymona Kopycińskiego ${ }^{65}$, P. Adama Jordana ${ }^{66}$, P. Stefana Chmieleckiego ${ }^{67}$ i Pana Ludwika Poniatowskiego ${ }^{68}$, iż godnego opatrzenia na mają i prosieli za niemi, żeby Jego Książęca Mość przynajmniej po piąci tysięcy złotych onym zapisał, na co Jego Ksiażęca Mość odpowiedział, iż nie po piąci, ale po dziesiąci tysięcy [ $k$. 772] złotych onym zapisuje.

Actum Lublini in curia Generosa Domina Anna Poniatowska ${ }^{69}$ die 6 Augusti 1619.

Seb[astian] K[ajek] n[otarius] $\mathrm{p}$ [ublicus] manu propria

e Obok podpisu księcia „oniusz okrorobgsk”, tak właśnie brzmiacy dopisek, świadczacy o tym, że umierający testator miał problem ze złożeniem poprawnego podpisu i podejmował tę próbę dwukrotnie. Poniżej „PP. Stephanowi”, co miało być zapewne początkiem nowego zdania.

${ }^{64}$ Chodzi tu o matkę księcia Janusza Pawła - Annę z Kostków ks. Ostrogska (1575-1635), wojewodzinę wołyńską, która miała być egzekutorką tego testamentu.

${ }^{65}$ Szymon Kopyciński h. Kopacz (zm. 1631), póżniej starosta petrykowski i znany dowódca wojsk nadwornych Stanisława Lubomirskiego. Por. S. Żu rkowski, op. cit., s. 49; A. Boniecki, Herbarz..., t. XI, Warszawa 1907, s. 124.

${ }^{66}$ Adam Jordan z Zakliczyna h. Traby (zm. ok. 1645), przedstawiciel znanej rodziny małopolskiej, syn Jana, w 1628 r. starosta mszański. Por. A. Boniecki, Herbarz..., t. IX, Warszawa 1906, s. 78-79.

67 Stefan Chmielecki h. Bończa (zm. 1630), sławny zagończyk w służbie Ostrogskich i Zamoyskich. Później choraży bracławski i wreszcie (w 1629 r.) wojewoda kijowski. Por. W. Dobrowols ka, Chmielecki Stefan, [w:] PSB, t. III, Kraków 1937, s. 318-320.

${ }^{68}$ Ludwik Poniatowski, pułkownik, arianin, znany $z$ awanturnictwa. Ożenił się z Anną Ziemecka, wdowa po Stanisławie Stadnickim „Diable łańcuckim”, i toczył liczne spory ze swoimi pasierbami nazywanymi „Diablętami”. Por. W. Łoziński, Prawem i lewem. Obyczaje na Czerwonej Rusi w pierwszej połowie XVII wieku, t. II (Wojny prywatne), wyd. 5, Kraków 1957, s. 358, 360, 370, 377.

69 Anna $z$ Ziemeckich, żona Ludwika Poniatowskiego, wdowa po Stanisławie Stadnickim „Diable” z Łańcuta. W należącym do Poniatowskich dworze zmarli obaj 


\section{Bibliografia}

\section{ŹRódea ARChIWALNe}

Archiwum Główne Akt Dawnych w Warszawie [AGAD]

Archiwum Potockich z Łańcuta [APŁ], nr 1532, 1544.

Metryka Koronna 182.

Archiwum Państwowe w Lublinie

Lubelskie grodzkie, Relacje, nr 49.

\section{ŹRÓDEA DRUKOWANE}

Jerlicz J., Latopisiec albo kroniczka, wyd. K.W. Wójcicki, Warszawa 1853.

Komorowic A., Panegyricus... Constantino Duci Ostrogiae... dum salvus et incolumis in Regnum Poloniae redirect... dedicatus et oblatus, Cracoviae 1615.

Kus J., Testament księcia Janusza Pawła Ostrogskiego z 1619 r., „Zeszyty Muzealne. Muzeum w Jarosławiu” 1997/1998, R. II, z. 2, s. 19-21, 116-119.

Malewska H., Listy staropolskie z epoki Wazów, Warszawa 1959.

Niesiecki K., Herbarz polski, wyd. J.N. Bobrowic, t. V, Lipsk 1840.

Niesiecki K., Herbarz polski, wyd. J.N. Bobrowicz, t. VII, Lipsk 1841.

Ossoliński J., Pamiętnik, oprac. W. Czapliński, Warszawa 1976.

Ossoliński Z., Pamiętnik, oprac. J. Długosz, Warszawa 1983.

Pietas in ilustrissimum Dominum Janussium Paulum Ducem in Ostrog etc. a nobili iuventute Collegii Kostkoviani SJ brevi threnodia Jaroslaviae mense Domitiani exhibita, Zamosci 1619.

Pisma Stanisława Żółkiewskiego kanclerza i hetmana, wyd. A. Bielowski, Lwów 1861.

Starowolski S., Monumenta Sarmatarum, Cracoviae 1655.

Śliwski J., Na Iasnie oświeconego Adama Constantego Xiążęcia Ostrogskiego woiewodzica wołyńskiego żałosny pogrzeb kazanie... w Jarosławiu, na dzień 7 czerwca zgotowane, Kraków 1618.

Trepka Nekanda W., Liber generationis plebeanorum („Liber chamorum”), wyd. W. Dworzaczek, J. Bartyś, Z. Kuchowicz, red. W. Dworzaczek, cz. 1 (Wstępy wydawców i tekst), Wrocław-Warszawa-Kraków 1963.

[Wolbromczyk K.], Charisterion ob felicem ecoptatum illustrissimi Principis Constantini Ostrogii Ducis ab exteris nationibus favente, coleo in patriam reditum. A nobili studiosaque iuventute Collegii Jarroslaviensis SJ... datum anno Christi 1615, Leopoli [1615].

bracia Ostrogscy. Nie należy jednak doszukiwać się tu jakiejś sensacji, gdyż było to miejsce, gdzie młodzi książęta zwykli się zatrzymywać w czasie swojego pobytu w Lublinie, mimo że posiadali własny dworek na Białkowej Górze w lubelskiej jurydyce Czwartek. Por. J. Ku s, „Wielkie...”, s. 15. 
Wyciagi z summaryusza Aktów Trybunału Lubelskiego, [w:] Źródła dziejowe, t. XXI (Polska XVI wieku pod wzgledem geograficzno-statystycznym, t. X, Ziemie ruskie, Ukraina [Kijów-Bracław], dział II-gi), wyd. A. Jabłonowski, Warszawa 1894 , s. 3-654.

Żurkowski S., Żywot Tomasza Zamojskiego, kanclerza w. kor., wyd. A. Batowski, Lwów 1860.

\section{OpRacowania}

Anusik Z., Glosa do dziejów rodu książąt Ostrogskich, „Przegląd Nauk Historycznych" 2008, R. VII, nr 1, s. 127-210.

Anusik Z., Z dziejów rodu książąt Ostrogskich, [w:] Z. Anusik, Studia i szkice staropolskie, Łódź 2011, s. 408-494.

Baranowycz O., Zaludnnienja wołynskoho wojewodstwa $w$ perszyj połowynni XVII st., Kyijw 1930, s. 40.

Biedrzycka A., Tazbir J., Starowolski (Starovolscius) Szymon, [w:] Polski słownik biograficzny, t. XLII, Warszawa-Kraków 2003-2004, s. 356-361.

Boniecki A., Herbarz polski, t. I, Warszawa 1899.

Boniecki A., Herbarz polski, t. II, Warszawa 1900.

Boniecki A., Herbarz polski, t. III, Warszawa 1900.

Boniecki A., Herbarz polski, t. IX, Warszawa 1906.

Boniecki A., Herbarz polski, t. XI, Warszawa 1907.

Boniecki A., Poczet rodów w Wielkiem Księstwie Litewskiem w XV i XVI wieku, Warszawa 1887.

Chynczewska-Hennel T., Ostrogski Janusz, [w:] Polski słownik biograficzny, t. XXIV, Wrocław 1979, s. 481-486.

Czapliński W., Długosz J., Życie codzienne magnaterii polskiej w XVII wieku, Warszawa 1976.

Długosz J., Podział latyfundium Ostrogskich $w$ roku 1621, „Acta Universitatis Wratislaviensis" nr 8, Historia XVI, 1969, s. 3-15.

Dobrowolska W., Chmielecki Stefan, [w:] Polski słownik biograficzny, t. III, Kraków 1937, s. 318-320.

Dobrowolska W., Książ̨ta Zbarascy $w$ walce $z$ hetmanem Żółkiewskim, Kraków 1930.

Dworzaczek W., Hetman Jan Tarnowski. Z dziejów możnowładztwa małopolskiego, Warszawa 1985.

Instrukcja wydawnicza dla źródeł historycznych od XVI do połowy XIX wieku, red. K. Lepszy, Wrocław 1953.

Jakowenko N., Druga strona lustra. Z historii wyobrażeń $i$ idei na Ukrainie XVI-XVII wieku, Warszawa 2010.

Jakowenko N., Ukraijnska szljachta $z$ kinca XIV-do seredyny XVII stolittja. Wołyn' i Centralna Ukraijna, Kyijw 2008.

Kardaszewicz S., Dzieje dawniejsze miasta Ostroga. Materyały do historyi Wołynia, Warszawa-Kraków 1913. 
Kempa T., Dzieje rodu Ostrogskich, Toruń 2003.

Kempa T., Konstanty Wasyl Ostrogski (ok. 1524/ 1525-1608), wojewoda kijowski i marszałek ziemi wołyńskiej, Torun 1997.

Kłaczewski W., Sanguszko Adam Aleksander, [w:] Polski słownik biograficzny, t. XXXIV, Wrocław 1992-1993, s. 464-467.

Kowalska H., Ostrogska Anna z Kostków, [w:] Polski słownik biograficzny, t. XXIV, Wrocław 1979, s. 478-479.

Kowalska H., Ostrogski Aleksander, [w:] Polski słownik biograficzny, t. XXIV, Wrocław 1979, s. 480.

Kuchowicz Z., Człowiek polskiego baroku, Łódź 1992.

Kus J., „Wielkie, ale krótko trwałe oyczyzny nadzieje...”. Adam Konstanty i Janusz Paweł książęta Ostrogscy, wojewodzice wołyńscy, „Zeszyty Muzealne. Muzeum w Jarosławiu” 1997/1998, R. II, z. 2, s. 7-19.

Litwin H., Napływ szlachty polskiej na Ukraine 1569-1648, Warszawa 2000.

Łoziński W., Prawem i lewem. Obyczaje na Czerwonej Rusi w pierwszej połowie XVII wieku, t. II (Wojny prywatne), wyd. 5, Kraków 1957.

Makara J., Dzieje parafii jarosławskiej od poczatku do r. 1772, Jarosław 1936.

Mazur K., W strone integracji z Korona. Sejmiki Wołynia i Ukrainy w latach 1569-1648, Warszawa 2006.

Pietrzak J., Akademickie niestatki, czyli o niechlubnym żywocie polskich studentów w podróżach edukacyjnych po Europie Zachodniej od XVI do XVIII wieku, „Biuletyn Historii Wychowania” 2014, nr 32, s. 7-27.

Piskadło A., Wstęp, [w:] S. Starowolski, Polska albo opisanie położenia Królestwa Polskiego, oprac. A. Piskadło, Kraków 1976, s. 6-53.

Rolle A., O dziedziczności obłąkania, „Przegląd Lekarski: Organ Towarzystw Lekarskich Krakowskiego i Galicyjskiego" 1889, nr 5, s. 61.

Seredyka J., Sejm 1618 roku, Opole 1988.

Tomczak A., Kostka Krzysztof, [w:] Polski słownik biograficzny, t. XIV, WrocławWarszawa-Kraków 1968-1969, s. 350-351.

Urzędnicy województw bełskiego i ziemi chełmskiej XIV-XVIII wieku. Spisy, oprac. H. Gmiterek, R, Szczygieł, red. A. Gąsiorowski, Kórnik 1992.

Urzędnicy wołyńscy XIV-XVIII wieku, oprac. M. Wolski, Kórnik 2007.

Wolff J., Kniaziowie litewsko-ruscy od końca XIV wieku, Warszawa 1895. 


\section{Short life and unexpected death of a young magnate Prince Janusz Pawel Ostrogski and his last will of August 6, 1619}

\footnotetext{
The article is devoted to prince Janusz Paweł Ostrogski (1597-1619). He was 1 a descendant of one of the most powerful magnate families in the Polish-Lithuanian Commonwealth. After the early death of his father, the Volyn voivode Aleksander, he was brought up, together with older brother, by his mother. She led them to conversion from Orthodoxy to Catholicism. In the years 1611-1615 the young Ostrogski brothers took an educational journey around the Western Europe. After returning to the fatherland they took over a huge latifundium from their mother. Both brothers were known of their rude lifestyle and promiscuity. They were infected with syphilis, which was a cause of their premature death. After the death of his older brother, Janusz Pawel became one of the greatest landowners in the Polish-Lithuanian Commonwealth. He was going to get married. Death however, surprised him on his way to the home of his future father-in-law. The prince made an interesting last will before his death, the critical edition of which was included as an annex to this study.
}

Keywords: Prince Janusz Paweł Ostrogski, Polish magnates, the history of Polish-Lithuanian Commonwealth in $17^{\text {th }}$ century, Old Polish last wills, source edition. 